\title{
14 (Momentarily) drifting into ideocracy in Central Europe
}

\author{
The case of Law and Justice and Fidesz
}

\author{
Grzegorz Pożarlik
}

\section{Introduction}

I argue in what follows that the current nationalism-populism nexus in Central Europe increasingly displays features of ideocratic drift. The concept of ideocracy was recently revamped in the scholarly debate by - among others Roger Griffin, ${ }^{1}$ Uwe Backes and Steffen Keilitz, ${ }^{2}$ Jaroslaw Piekalkiewicz and Alfred Wayne Penn, ${ }^{3}$ as well as Johannes Gerschewski. ${ }^{4}$ The common denominator of the recent conceptualisations of ideocracy - as Johannes Gerschewski rightly points out - is the nineteenth century German scholarly debate on fanaticism in political systems. ${ }^{5}$ In my analysis of current ideocratic drift in Central Europe I follow the Uwe Backes and Steffen Keilitiz approach linking ideocracy with 'utopian legitimation of power'6 with specific reference to Roger Griffin's seminal: The Legitimising Role of Palingenetic Myth in Ideocracies. ${ }^{7}$ Although Griffin focused in his study on ideocracy on the analysis of the birth and evolution of interwar totalitarianism in Europe, I argue that the concept of ideocracy itself seems strikingly relevant when we wish to understand and explain the rising illiberal appetite or what Jacques Rupnik calls 'democratic backsliding'8 in Central Europe.

Thus, a major assumption of this analysis is that ideocracy, understood as an 'abuse of power in a system of political pluralism's leading to a palingenetic nomos utopia, reveals a particular relevance to the current populist turn in Central Europe. To complement the analytical matrix of this study, I refer to the very term of populism as understood along the lines of Jan-Werner Müller's conceptualisation developed in What Is Populism? ${ }^{10}$ When explaining this thesis, I explore three major rhetorical dyads of current Central European ideocratic drift, namely: the real people vs. the corrupt elite, the will of the sovereign vs. the ancien regime rule of law. I conclude by referring to the reinvention of the ethno-organic vision of the nation state as an ideological legitimation of the re-narrative of the post-1989 transformation in Central Europe. 


\section{Ideocracy in contemporary Central Europe. The concept and its explanatory power}

The illiberal revolution recently heralded by a number of populist leaders in Central Europe should not be seen as a surprise. ${ }^{11}$ After all, liberal democracy fatigue has been steadily growing for at least a decade. Frozen populist sentiments erupted on the wave of 'revolt of the masses' - using José Ortega y Gasset's ${ }^{12}$ term - against the proclaimed moral corruption of liberal elites. Fidesz in Hungary, as well as Law and Justice (Prawo i Sprawiedliwość, PiS) in Poland, have built their political reputation by appealing to the collective appetite for the will of the real people, one which should determine boundary drawing between the legitimate and the illegitimate in the public domain.

The ideology of the will of the real people as a supreme constitutional norm became the leitmotif of a re-ordering of the political system. Fundamental values of the constitutional rule of law, such as the separation of powers, have been replaced by a re-ordering of the constitutional system according to the premises of social justice as seen through the prism of an ethno-organic vision of the national community.

This illiberal revolution in Central Europe has triggered concern in the European Union and its member states, as well as in international institutions, over the condition of the democratic rule of law in Poland and Hungary. In consequence, in reaction to a number of controversial regulations introduced to the Polish and Hungarian legal systems, the European Commission and the European Parliament initiated proceedings based on Article 7 of the Treaty on European Union on the democratic rule of law and founding values. ${ }^{13}$ Also, the Court of Justice of the EU adopted a number of rulings highlighting the inconsistency between the fundamental values of the EU as stipulated in the Article 2 of the Treaty on European Union and institutional developments in the judiciary and legal systems of Poland and Hungary. ${ }^{14}$ Most recently, the European Council adopted a rule of law conditionality clause with regard to the payment of EU budget funds for 2021-2027. ${ }^{15}$

Against the backdrop of these formal developments we can find a lively scholarly debate about the essence and substance of the erosion of liberal democracy and the populist turn in Central Europe. Many have attempted to understand and explain the meaning of the constitutional U-turn in Poland and Hungary, as well as in the wider Central European region. ${ }^{16}$ In an otherwise pretty polyphonic discourse, we can discern a widespread tendency to apply analogical reasoning ${ }^{17}$ to the analysis of recent constitutional transformations.

One question seems to prevail in this debate: if the political systems in Poland and Hungary cannot be seen in terms of the fully fledged democratic rule of law, as those built on the separation of powers, what precisely are they then? In this case it is somehow natural that policy-makers and scholars tend to use - and sometimes even abuse - history to justify their claims about the nature of the new system. 
Being aware of the limitations of making a one-to-one historical analogy, I apply Roger Griffin's ideocracy as an analytical tool enabling us to understand and explain the current nationalism-populism nexus in Central Europe. I argue that consistently combining Griffin's notion of ideocracy with JanWerner Müller's conceptualisations of populist ideologies brings us closer to answering the question about the nature of the nationalism-populism nexus in a period which is bearing witness to the return of charismatic national leadership in Central Europe.

The construction that Roger Griffin built assumes the following:

a complex, dynamic, but non-dialectical and non-determinist relationship between the economic (structural) and ideological (super-structural) factors conditioning the evolution of history as well as among the social elites imposing the hegemony of certain political ideas and the subjects of an autocratic elite, who far from always being passive victims, may in some circumstances become its enthusiastic supporters and the protagonists of the historical transformation in their own right. This results in a fluctuating, irreducibly complex role played by ideology in establishing consensual legitimation, which can never be the product of the power of ideas in itself. ${ }^{18}$

The key component of Griffin's architecture is the concept of a 'palingenetic community', emerging as an outcome of a charismatic leadership proclaiming a new order inspired by the idea of national rejuvenation. ${ }^{19} \mathrm{~A}$ palingenetic community is built upon an accompanying palingenetic myth - a myth of belonging to a community of memory, morality and dignity. The palingenesis in this case means the collective affirmation of a glorious past as well as moral imperative of each true believer of the national community of the need to engage in building a new social order based on ethno-organic solidarity and charismatic leadership. Interestingly, Griffin recalls Eric Hoffer's classic study on the construction of mass movements in totalitarian societies to explain the appetite of an individual to become member of a reborn national community. Hoffer's true believer invents an individual sense of belonging to a palingenetic community:

[The true believers'] innermost craving is for a new life - a rebirth - or, failing this, a chance to acquire new elements of pride, confidence, hope, a sense of purpose and worth by identification with a holy cause. An active mass-movement offers them opportunities for both. If they join the movement as full converts they are reborn to a new life in its close-knit collective body, or if attracted as sympathizers they find elements of pride, confidence, and purpose by identifying with the efforts, achievements, and prospects of the movement. ${ }^{20}$

In order to explore the current nationalism-populism nexus in Central Europe by means of explaining the populist legitimation of ideocratic movements 
in contemporary Central Europe, we need to complement Griffin's study with Jan-Werner Müller's account of the recent populist turn. What makes Griffin's and Müller's contributions complementary is their focus on the ideological appeal of the moral exceptionalism of anti-pluralist and antielitist rhetoric heralded by contemporary charismatic populist leaders. Thus, Griffin's account of the longing for a mythical, rejuvenated national community is complemented by Müller's insight on the moral exceptionalism of 'we, and we alone represent the real people or the silent majority' rhetoric. ${ }^{21}$

Müller's conceptualisation of recent populism is deeply rooted in the belief that anti-pluralist and anti-elitist rhetoric is feeding a growing appetite in Europe as well as across the Atlantic for the de-legitimation of liberal values as the foundation of an open and democratic society and the rule of law. As Müller argues: 'Populists deny the legitimacy of all other contenders for power and also suggest that citizens who do not support them can have their status as properly belonging to the people put in doubt. ${ }^{22}$

The nationalism-populism nexus in Central Europe, as seen through the conceptual lens of Müller's theory of populism, would then be framed by a moral versus an empirical reality power struggle or 'counting versus feeling majorities' as Christoph Möllers argues. ${ }^{23}$

In the next part of this chapter I will touch upon the question of why populists are so dominant in Central Europe by diagnosing a set of two dyads: 'the real people versus a corrupted elite', 'the will of the sovereign versus the ancien régime rule of law'.

\section{Why are populists so popular in Central Europe? Ideocracy as a speech act: speaking on behalf of the real people}

The ideocratic character of the nationalism-populism nexus in Central Europe can be clearly seen through the conceptual prism of the rhetorical dyads which populist leaders have introduced into the public sphere. The nature of these dyads reveals a binary, Manichean vision of the nation, state and society. It is precisely this binary vision of politics which has appealed to many and made populism and populists so dominant.

Speaking on behalf of the 'real people' and listening to them have become key rhetorical constructs, ones which are meant to consolidate the common belief that there is just one legitimate way of understanding who constitutes the nation, who belongs properly to the national community and who is to be considered, as Jarosław Kaczyński has put it, as among the 'worst sort of Poles' who should be deprived of their truly patriotic feelings. ${ }^{24}$ Assuming the role of a speaker of the real people is essential in the overall strategy of the de-legitimisation of opponents as representatives of a somewhat 'unreal people' or 'corrupt elite'. .25

In the case of the populist leaders in Poland and Hungary, the monopolisation of speaking on behalf of the real people is meant to petrify the ideocratic model of state power. Only the leaders of the nation can properly 
address what real people want, as it is they, and they alone, who feel the pulse of the nation. Feeling the beating heart of the nation also means they have a legitimate right to stand above and move beyond any standard rules and procedures of the democratic public sphere. This in itself constitutes a radical departure from what the proponents of illiberal revolution often call ancien régime left-liberal ideology. As explained convincingly by Bojan Bugarič:

The role of the populist leader is to do what the people want. The formal structures of liberal democracy have to be put aside if they are preventing the populist leader to fulfil his role. Populist leaders distrust all the traditional institutions of liberal democracy that stand between them and the wishes of the people. As a result, many of the ECE nationalist populist parties openly flout the rule of law and explicitly reject the values of liberal democracy. A corollary of this view is the strong personalization of power, reflected in the fact that strong leaders like Orbán and Kaczyński have managed to concentrate almost unlimited political power in their hands. ${ }^{26}$

The rise of populist sentiment in Central Europe needs to be seen, however, in a much broader perspective of a steady descent into anomic society. Populist tendencies, which took the form of ideotional autocracy, did not appear out of thin air. We should have seen it coming over the course of more than 30 years of turbulent and yet unfinished democratic transformation after 1989. One of the consequences of the deep social, political and economic transformations in post-1989 Central Europe has been the petrification of a 'winners versus victims' divide that has shaped the minds of the many.

The crystallisation of the anomic structure of a traumatic society is a background for the rise of nostalgia towards a new type of l'état providence, which would even up the odds and make up for the harm that post-communist elites have done to the common people as a result of the systemic changes after 1989. Incorporating Piotr Sztompka's concept of 'trauma in social change' into the analysis of the post- 1989 social transformation reality in Central Europe is based on the enduring relevance of the concept of cultural trauma, which depicts the situation of 'sudden', 'systemic', 'new-order', 'revolutionary' transformation. ${ }^{27}$ As explained by Piotr Sztompka:

There cannot be any doubt that the collapse of communism was a traumatogenic change par excellence (...). What makes the collapse of communism a particularly interesting example of traumatogenic change is [also] that it was a 'trauma of victory' (to paraphrase Durkheim's 'anomie of success'). The change was almost universally judged as beneficial, progressive, often welcome with enthusiasm, and yet it has turned out to produce trauma, at least for some segments of post-communist societies. Finally, the traumatic sequence is in this case still uncompleted, the transformation with all that it implies is still in the making, the 
revolution is unfinished, providing fully actual laboratory for the theory of cultural trauma. ${ }^{28}$

Populists enjoy support because they have skilfully identified and addressed some of the main anxieties that have arisen. The leaders, discerning the vacuum stemming from societal anomy, have offered an ideocratic vision of an organic society based on solidarity. As is natural for any traumatic syndrome, there was insecurity, uncertainty and injustice caused by rapid change and orchestrated - as it was widely believed - by a corrupt elite and its admiration of the mechanic division of labour within the realms of a turbo-capitalist society. The antidote turned out to be the idea of an ethno-organic national community and its charismatic leadership. Indeed, l'état providence nostalgia found its resonance in the rhetoric of an indigenous Central European welfare state.

One of the sharpest examples of the rhetoric of social policy finding its own way is Viktor Orbán's National Strategy for Cooperation of 2012. ${ }^{29}$ Abandoning the past and opening up a new chapter in national history became the motto of the 'time for change' narrative. As Dorottya Szikra rightly observes, pointing to the 'failure' of the Western-style welfare state was meant to legitimise the need to build a new model welfare state. ${ }^{30}$ As Viktor Orbán himself emphasised:

All states have to accomplish the correction of the welfare state. This is more difficult in the West because they have full-fledged welfare states but not so difficult in Central Europe as welfare states are not created here. We tumble along the ruins and semi-finished buildings of post-communism, but here we have no welfare states. Our program is to establish instead of the Western-style welfare state that is not competitive, a workbased society. ${ }^{31}$

\section{The will of the sovereign vs. the ancien regime rule of law. Towards an ideocratic fundamental law system}

Replacing the ancien régime rule of law with a constitutionalisation based on the will of the sovereign, i.e. the will of the real people, is another rhetorical construct that features in the current nationalism-populism nexus in Central Europe. We, the people has lost its original connotation with the demos and has begun to denote an ethnos type of constitutional order. The ancien régime constitutional system had been identified as a major feature of so called legal 'impossibilism', which - according to Jarosław Kaczyński and the ruling United Right (Zjednoczona Prawica) coalition leaders - needs to be removed if the will of the people, meaning the will of the sovereign, is to be fully respected and made a reality. ${ }^{32}$

The flagship speech calling for turning constitutional justice into political justice was Kornel Morawiecki's parliamentary address, where he claimed 
that: 'Law is something important but it is not sacred. (...) Above the law stands the good of the Nation. If law interferes with this good, we shall not treat law as something inviolable or unchangeable. What I say is this: law shall serve us! Law that does not serve the nation is lawlessness. ${ }^{33}$

In light of such rhetoric, all those opposing the primacy of the will of the people as a fundamental law over the constitutional rule of law, including those occupying the highest positions in the judiciary, act against the will of the sovereign and are therefore considered illegitimate in their claims. As the leader of Poland's ruling Law and Justice declares: 'In a democracy, the sovereign is the people, their representative parliament and, in the Polish case, the elected president. If we are to have a democratic state of law, no state authority, including the Constitutional Tribunal, can disregard legislation'. ${ }^{34}$

In the same vein we can find Viktor Orbán and his Fidesz party re-drawing the boundary between the past and the present ideal of popular sovereignty. Robert Csehi explains this process in an insightful manner:

He [Viktor Orbán] managed to reconstruct 'the elite' from 'representatives of the past' to a 'homo sorosensus', and widened the scope of 'the people' from 'we, Hungarians' to 'we, the sovereign nations'. Similarly, Orbán renewed the conflict between the ever changing elite and 'the people', turning from economic-driven to identity politics. Finally, Orbán reinvented a toolkit of new, innovative measures that reflected a preference for greater popular sovereignty. ${ }^{35}$

Speaking on behalf of the people is also a matter of defending the will of the people when the need arises. In reaction to Article 7 TEU, launched against Hungary and Poland by a number of EU institutions, the argument about the ultimate right of the people to defend what they believe is right for them was advanced. Both Law and Justice's and Fidesz's leaders challenged the legitimate character of the concerns raised by the European Parliament and the European Commission in regard to the serious breaches of standards in the rule of law in Hungary and Poland.

Viktor Orbán, in a passionate speech given to the European Parliament in defence of the Hungarian government's position under the Article 7 proceeding, manifested a classic outsider cannot judge approach to popular sovereignty in the international system. He denied the legitimate right of the European Parliament - of which his Fidesz party is a member- to express concerns about disrespect being shown to the fundamental values upon which the European Union is built.

'I stand here now', Viktor Orbán went on to argue, 'and I see that Hungary is being arraigned by people who inherited democracy, not needing to assume any personal risk for the pursuit of freedom. [...] the report before you is an affront to the honour of Hungary and the Hungarian people. Hungary's decisions are made by the voters in parliamentary elections. 
What you are claiming is no less than saying that the Hungarian people are not sufficiently capable of being trusted to judge what is in their own interests. You think that you know the needs of the Hungarian people better than the Hungarian people themselves'. ${ }^{36}$

\section{Re-writing the corrupt past and writing the proper present and the future}

As already emphasised, after Uwe Backes and Steffen Keilitz, the utopian legitimation of power is a constitutive component of any ideocratic regime. ${ }^{37}$ In this sense, ideocratic rulers need to be - at least in declaratory terms driven by a certain ideological utopianism. ${ }^{38}$ Consequently, it may be assumed that: 'Ideocracies require existence of an ideology-based regime party, which is used for social transformation, control, monitoring, and effective combating of enemies. It also facilitates the ideologized participation of citizens in the political regime'. ${ }^{39}$

In some post-1989 Central European ideocratic narratives - Poland and Hungary especially - rewriting the history of the post-1989 change became the leitmotif of the ideology of national revival or national recovery. Thus, the ideocratic flavour of the nationalism-populism nexus in contemporary Central Europe can be felt in the reinvigoration of the rhetoric of nineteenth century national sovereignty as the background for the re-telling of the post1989 transformation in Central Europe. In the case of Poland, for that matter, the new foundation myth which has been articulated in populist rhetoric, one coined to justify the ethos of a new fourth republic, refers to the idea of national recovery, sanacja. The myth of the interwar national recovery also assumed the moral recovery of the nation and that of the state.

Perhaps unsurprisingly, analogical reasoning had been involved in the ideological legitimation of the sanacja myth as the inspiration for building the ethos of the fourth republic on the ruins of the morally corrupt regime of the third republic. The round table negotiations held in the spring of 1989 between the Communist Party leadership and the Solidarity trade union, which led the first semi-free elections to be held on 4 June 1989 and the establishment of the first non-communist government since 1945, soon began to be contested. A portion of the anti-communist opposition saw it as an illegitimate deal, a symbol of the national betrayal by the corrupt elites of the emerging third republic.

After 2015, the massive electoral victory of Law and Justice under the charismatic leadership of Jarosław Kaczyński saw the rhetoric of national moral recovery picking up momentum. The entire period of the post-1989 history of Poland became to be narrated in populist rhetoric in terms of a story of national betrayal, one deserving of moral condemnation, reckoning and punishment. The time has apparently come for a new republic based on emotional continuity with the ethos of the late second republic and the rhetoric of the moral recovery of the state - it was time for a new state, a new society and a 
new elite. All those contesting such an interpretation of Poland's post-1989 history were regarded as lacking true patriotic feeling.

Michael Bernhard and Jan Kubik explain this rhetoric in terms of a 'mnemonic' revolution - 'the new' politics of memory. ${ }^{40}$ Writing the new and true national narrative is fighting an enemy who falsifies the past in order to retain his privileges. Mnemonic actors - Bernhard and Kubik argue - challenge the ancien régime elite narrative of the post-1989 foundation myth of the republic. ${ }^{41}$ In doing so '[T]hey often treat history instrumentally in order to construct a vision of the past that they assume will generate the most effective legitimation for their efforts to gain and hold power'. ${ }^{42}$

Following Bernhard's and Kubik's terminology, we may assume that the current ideocratic drift in Central Europe is led by 'mnemonic warriors' who 'tend to espouse a single, unidirectional, mythologized vision of time [...] The alternative visions of the past - by definition "distorted" - need to be delegitimized or destroyed. The proponents of such visions need to repent or leave public life. As the holders of the truth, mnemonic warriors tend to be, therefore, proselytizers. ${ }^{93}$

The new state ideology also inspired followers of the Fidesz revolution. The new state was meant to be an illiberal national state, whilst the Western European liberal state became the significant other against which Fidesz developed its own identity. Viktor Orbán made the ultimate goal of the Fidesz revolution clear:

The new state that we are constructing in Hungary is an illiberal state, a non-liberal state. It does not reject the fundamental principles of liberalism such as freedom, and I could list a few more, but it does not make this ideology the central element of state organisation, but instead includes a different, special, national approach. ${ }^{44}$

Similarly, Law and Justice's ideology of 2015 was a revolutionary rhetoric applied to systemic change in much the same way as in Hungary after Fidesz's 2010 electoral victory. Strikingly, Jarosław Kaczyński admitted that his idée fixe is 'to have Budapest in Warsaw one day'. ${ }^{45}$ The Law and Justice leader felt inspired by Viktor Orbán's illiberal national state revolutionary vision. As rightly noted by Anna Szilágyi and András Bozóki, 'revolutionary rhetoric' had much larger connotations than just a huge electoral victory and the defeat of political opponents. ${ }^{46}$

The metaphor of revolution was further transposed into political engineering of putting an end to the liberal ancien régime and the imperative to build a new system. Viktor Orbán left no doubt that:

Today in Hungary we learned a historical lesson, that is the lesson of the past 20 years, that is the lesson of the regime change, and that is as follows: it is impossible to change a regime, a regime can be only brought down and overthrown, overthrown and replaced by a new one. ${ }^{47}$ 
An ongoing reference to historical revolutions which shaped the meaning of Hungarian identity in terms of national revival is clearly evident in the analogical reasoning ${ }^{48}$ of the post-2010 period. Again, Viktor Orban passionately recalled that:

There were several such moments in Hungarian history. In the past centuries the revolution in 1948 or the revolution in 1956 were like this, and for us the regime change in 1990 was also like this. And today, we Hungarians have arrived again at such a day. We arrive at a new one, among the rare great days of history, Hungarian history. ${ }^{49}$

\section{Concluding remarks}

The rise of the nationalistic and populist mood that we have seen in the last decade in Central Europe and the Western Balkans has been part of a much larger global trend. However, there are some similarities and clear significant differences between these trends. As Miran Lavrič and Florian Bieber notice:

There is evidence of autocratic and populist leaders across the globe, from the Philippines to the United States, gaining power in a wide range of regimes, from consolidated democracies to hybrid regimes. While it might be hard to identify a global pattern to explain the rise of such regimes, there has been a distinct democratic decline in a number of regions, including in Central and Southeastern Europe. ${ }^{50}$

Lavrič and Bieber illustrate the conceptual ambiguity and elusiveness surrounding the global democratic backsliding debate by highlighting Ronald F. Inglehart's and Pippa Norris' thesis correlating economic insecurity with a cultural backlash as providing the backdrop for a major shift in voting preferences and, above all, a major change in the value systems of contemporary societies everywhere. ${ }^{51}$ As Inglehart and Norris claim: 'the classic economic Left-Right cleavage in party competition is overlaid today by a new Cultural cleavage dividing Populists from Cosmopolitan Liberalism'. ${ }^{52}$

On the other hand, however, Florian Bieber insightfully notes that one size does not fit all. ${ }^{53}$ 'Citizens of Austria', Bieber argues, 'do not turn nationalist because their counterparts in the United States do, nor are the structural similarities so great that there is a universally fertile ground for nationalist movements from India to Kentucky. Nationalism, authoritarianism and populism are also easily conflated, while they can be mutually reinforcing they are distinct and can occur independently'. ${ }^{54}$

As argued above, the genus proximus et differentiam specificam of the Central European nationalism-populism nexus is a palingenetic imprint of ideocratic rhetoric. One of the key elements of the palingenetic myth of ideocracy is analogical reasoning, which assumes the form of an ideologically justified interpretation of the past which aims to legitimise the present. 
What seems a particularly promising direction for further research on the nationalism-populism nexus is the identification of factors determining these similarities and differences in analogical reasoning. This should encompass both the political actors engaged in this populist rhetoric as well as scholars themselves applying analogical reasoning in their research.

A case in point here is Christopher Browning's The Suffocation of Democracy. ${ }^{55}$ 'As a historian specializing in the Holocaust, Nazi Germany, and Europe in the era of the world wars', Browning concluded insightfully,

I have been repeatedly asked about the degree to which the current situation in the United States resembles the interwar period and the rise of fascism in Europe. I would note several troubling similarities and one important but equally troubling difference... . .

Studying the current ideocratic drift in Europe and elsewhere seems, therefore, an equally risky but intriguing endeavour. It certainly deserves more attention among scholars dealing with the erosion of trust in democracy and the explosion of populism and nationalism in a period of widespread societal anomy.

\section{Notes}

1 Roger Griffin, 'The Legitimizing Role of Palingenetic Myth in Ideocracies', (2012), 9, Totalitarismus und Demokratie, 39-56.

2 Uwe Backes and Steffen Keilitz (eds), Ideocracies in Comparison: Legitimation Cooptation - Repression, (Routledge 2016).

3 Jaroslaw Piekalkiewicz and Alfred Wayne Penn, Politics of Ideocracy, (State University of New York Press 1995).

4 Johannes Gerschewski, 'Do Ideocracies Constitute a Distinct Subtype of Autocratic Regimes?', in Backes and Keilitz, (n 2), 88-105.

5 Ibid., 89.

6 Backes and Keilitiz, (n 2), 2.

7 Griffin, (n 1).

8 Jacques Rupnik, 'From Democracy Fatigue to Populist Backlash', (2007), 18, Journal of Democracy, 4, 17-25; Jacques Rupnik, 'The Spectre Haunting Europe: Surging Illiberalism in the East', (2016), 27, Journal of Democracy, 4, 77-87; Jacques Rupnik, 'Explaining Eastern Europe: The Crisis of Liberalism', (2018), 29, Journal of Democracy, 3, 24-38. See also Ben Stanley, 'Backsliding Away? The Quality of Democracy in Central and Eastern Europe', (2019), 15, Journal of Contemporary European Research, 4, 343-353.

9 Griffin, (n 1), 40.

10 Jan-Werner Müller, What is Populism?, (University of Pennsylvania Press 2016).

11 Cas Mudde and Cristóbal Rovira Kaltwasser, Populism: A Very Short Introduction, (Oxford University Press 2017). See also Takis S Pappas, 'Are Populist Leaders "Charismatic"? The Evidence from Europe', (2016), 23, Constellations an International Journal of Critical and Democratic Theory, 3, 379-390. 
12 José Ortega y Gasset, The Revolt of the Masses, (W W Norton \& Company 1st edn 1932, rev edn 1994).

13 See European Parliament resolution of 16 January 2020 on ongoing hearings under Article 7(1) of the TEU regarding Poland and Hungary (2020/2513(RSP)) www.europarl.europa.eu/doceo/document/TA-9-2020-0014_EN.html accessed 28 July 2020.

14 See Court of Justice of the European Union A.K. and Others (Independence of the Disciplinary Chamber of the Supreme Court) (C 585/18, C 624/18 and C 625/18), delivered on 19 November 2019 https://curia.europa.eu/jcms/upload/docs/applicat ion/pdf/2019-11/cp190145en.pdf accessed 28 July 2020.

15 Special meeting of the European Council (17, 18, 19, 20 and 21 July 2020) Conclusions, EUCO 10/20, www.consilium.europa.eu/media/45109/210720-eucofinal-conclusions-en.pdf accessed 28 July 2020.

16 Tímea Drinóczi and Agnieszka Bień-Kacała, 'Illiberal Constitutionalism: The Case of Hungary and Poland', (2019), 20, German Law Journal, 1140-1166. See also Ireneusz Paweł Karolewski and Roland Benedikter, 'Europe's New Rogue States, Poland and Hungary: A Narrative and Its Perspectives', (2017), Chinese Political Science Review, 2, 179-200.

17 Andrew Mumford, 'Parallels, Prescience and the Past: Analogical Reasoning and Contemporary International Politics,' (2015), 52, International Politics, 1-19.

18 Griffin, (n 1), 41.

19 Ibid., 50.

20 Eric Hoffer, The True Believer. Thoughts on the Nature of Mass Movements (New York 1951), 126 cited in Griffin, (n 1), 52.

21 Müller, (n 10), 10.

22 Jan-Werner Müller, 'The Rise and Rise of Populism', 6, www.bbvaopenmind.com/ wp-content/uploads/2018/03/BBVA-OpenMind-Jan-Werner-Muller-The-Riseand-Rise-of-Populism-1.pdf accessed 12 July 2020.

23 Christoph Möllers, 'They Do What They Want, But Do They Also Know What They Want?', (2016), 17, German Law Journal Brexit Supplement, 1, 142, 1 July 2016 cited in Müller (n 22).

24 Dawid Bunikowski, 'The Constitutional Crisis in Poland, Schmittian Questions and Kaczyński's Political and Legal Philosophy', (2018), 26, Journal of Contemporary European Studies 3: Special Issue Erosion of the Rule of Law in East Central Europe, 285-307.

25 Müller, (n 10).

26 Bojan Bugarič, 'Central Europe's Descent into Autocracy: On Authoritarian Populism', Minda Da Gunzburg Center for European Studies Harvard, CES Open Forum Series 2018-2019, 4 September 2018, 15 http://aei.pitt.edu/102391/1/Work ing-Paper-Central-Europes-Descent-into-Autocracy-On-Authoritarian-Popul ism-Publication.pdf accessed 13 July 2020.

27 Piotr Sztompka, 'The Ambivalence of Social Change: Triumph or Trauma?' WZB Discussion Paper, n P 00-001, Wissenschaftszentrum Berlin für Sozialforschung (WZB) Berlin 2000, 21, www.econstor.eu/handle/10419/50259, accessed 25 July 2020 .

28 Ibid.

29 András Deák, 'Hungarian Dances - The Origins and the Future of Viktor Orbán's Revolution', (2013), 11, Lithuanian Annual Strategic Review, 1, 145-168. 
30 Dorottya Szikra, 'Ideology or Pragmatism? Interpreting Social Policy Change under the "System of National Cooperation"', in Janos Matyas Kovacs and Balazs Trencsenyi (eds), Brave New Hungary. Mapping the 'System of National Cooperation', (Lexington Books, The Rowman \& Littlefield Publishing Group 2020), 226.

31 Cited in Szikra (n 30, 226), Viktor Orbán, Speech at the 21st EPP Congress, Bucharest, Romania, 17-18 October 2012 www.fidesz.hu/hirek/2012-10-19/orbannem-joleti-allam-hanem-munka-alapu-tarsadalom-epul- kepek/ accessed 20 July 2020.

32 Marcin Matczak, 'Poland's Constitutional Crisis: Facts and interpretations', The Foundation for Law, Justice and Society in association with the Centre for SocioLegal Studies and Wolfson College, University of Oxford, Policy Brief, 5, www.fljs. org/polands-constitutional-crisis-facts-and-interpretations accessed 21 July 2020.

33 Ibid., 6.

34 Christain Davies, 'Hostile Takeover: How Law and Justice Captured Poland's Courts', Freedom House Analytical Brief May 2018 https://freedomhouse.org/rep ort/analytical-brief/2018/hostile-takeover-how-law-and-justice-captured-polandscourts accessed 10 July 2020.

35 Robert Csehi, 'Neither episodic, Nor Destined to Failure? The Endurance of Hungarian Populism after 2010', (2019), 26, Democratization, 6, 1011-1027.

36 Cited in Gábor Halmai, 'Populism, Authoritarianism and Constitutionalism', (2019), 20, German Law Journal, 300.

37 Backes and Keilitiz, (n 2), 2.

38 Ibid.

39 Ibid.

40 Michael Bernhard \& Jan Kubik (eds), Twenty Years after Communism: The Politics of Memory and Commemoration (Oxford University Press, 2014).

41 Ibid.

42 Ibid., 4.

43 Ibid., 13. See also Mateusz Mazzini, 'A Three-Dimensional Model of Enlarging the Mnemonic Conflict: The Case of Poland Under Second Law and Justice Government', (2018), 31, Slovo, 1, 45-67 as well as Ljiljana Radonić 'Our' vs. 'Inherited' Museums. PiS and Fidesz as Mnemonic Warriors', (2020), 68, Südosteuropa, 1, 44-78.

44 Cited in Gellért Rajcsányi, 'Viktor Orbán’s Hungary: Orbanist Politics and Philosophy from a Historical Perspective', 131, www.kas.de/c/document_library/ get_file/uuid=8e914238-5bca-e235-e176-f8d502f4a33f\&groupId=288143 accessed 14 July 2020.

45 Seongcheol Kim, '... Because the Homeland Cannot Be in Opposition: Analysing the Discourses of Fidesz and Law and Justice (PiS) from Opposition to Power', (2021), 37, East European Politics, 2, 11, 332-351, DOI: 10.1080/ 21599165.2020.1791094 accessed 21 July 2020.

46 Anna Szilágyi and András Bozóki, 'Playing It Again in Post-Communism: The Revolutionary Rhetoric of Viktor Orbán in Hungary', (published online 15 April 2015), 18, Advances in the History of Rhetori, Supplement, 1, 153-166. Special Issue: Rhetorics of '1989' and After: Rhetorical Archaeologies of Political Transition, DOI:10.1080/15362426.2015.1010872.

47 Ibid., 14. 
48 I refer here to Mumford's claim according to which 'Analogical reasoning as a tool of rational decision making has increasingly become replaced by analogical reasoning as a tool of trenchant ideologically informed policy justification' [emphasis added], Mumford, (n 17), 1.

49 Cited in Szilágyi and Bozóki, (n 46), 13.

50 Miran Lavrič and Florian Bieber (2020), 'Shifts in Support for Authoritarianism and Democracy in the Western Balkans' Problems of Post-Communism, DOI:10.1080/10758216.2020.1757468 accessed 17 July 2020.

51 Ibid., 4.

52 Ronald F Inglehart and Pippa Norris, 'Trump, Brexit, and the Rise of Populism: Economic Have-Nots and Cultural Backlash', August 2016 https:// research.hks.harvard.edu/publications/workingpapers/Index.aspx 3, Paper for the roundtable on Rage against the Machine: Populist Politics in the U.S., Europe and Latin America, 2 September 2016, annual meeting of the American Political Science Association, Philadelphia, 3.

53 Florian Bieber, 'Is Nationalism on the Rise? Assessing Global Trends', (2018), 17, Ethnopolitics, 5, 519-540.

54 Ibid., 519-520.

55 Christopher Browning, 'The Suffocation of Democracy', The New York Review of Books (October 2018) 25 www.nybooks.com/articles/2018/10/25/suffocation-ofdemocracy accessed 15 July 2020.

56 Ibid. 